\title{
Fine Structure of B-Cell from Pancreas Pieces Incubated in Vitro
}

\author{
José Gomez-Acebo, Clemente Lophz-QuiJada and José Luis R-Candela \\ Instituto „G. Marañon“, Consejo Superior de Investigaciones Científicas, Madrid, Spain \\ Received February 8, 1966
}

Summary. Pieces of the tail of the rabbit pancreas were incubated in a shaking incubator with Ringer solution supplemented with glucose $(0.6 \mathrm{mg} / \mathrm{ml})$, pyruvate, fumarate and glutamate $(5 \mathrm{mM}$ each), in a gas phase of $95 \% \quad \mathrm{O}_{2}: 5 \% \quad \mathrm{CO}_{2}$ at $38^{\circ} \mathrm{C}$. There were no significant changes in the fine structure of the islet cells attributable to the incubation. Combined glutaraldehyde and osmium fixation of such incubated slices gave good preservation of the secretory products of the B-cells. The mechanisms of degranulation and regranulation of the B-cells were observed to be the same as those reported for the animal in vivo. The intensity of secretion differed depending upon whether the animals were killed after being knocked unsonscious or after being injected with a lethal dose of anaesthesia. B-cell secretion was more prominent in the former case. The method is considered to be valid for further studies on the mechanism of granule release and synthesis in the pancreas of rabbit.

Structure fine de la cellule bêta dans des tranches de pancréas incubées in vitro.

Résumé. Nous avons utilisé des fragments de queue de pancréas de lapin incubés à $38^{\circ} \mathrm{C}$. dans un appareil de Dubnoff. Le milieu d'incubation composé de Ringer additionné de glucose $(0.6 \mathrm{mg} / \mathrm{ml})$, de pyruvate, de fumarate et de glutamate $(5 \mathrm{mM})$ était ventilé avec un mélange $\mathrm{O}_{2}-\mathrm{CO}_{2}(95-5 \%)$ pendant toute la durée de l'incubation. - Nous n'avons remarqué aucun changement significatif de la structure fine des cellules des îlots de Langerhans attribuable au fait de l'incubation. La fixation combinée par glutaraldéhyde et osmium a permis d'obtenir une bonne protection des produits de sécrétion des cellules bêta. Nous avons pu remarquer que les mécanismes de dégranulation et de regranulation des cellules bêta étaient les mêmes que ceux notés lors de l'étude in vivo. L'intensité de la sécrétion varie suivant que l'animal est décapité après avoir été assommé ou après l'injection d'une dose léthale de produit anesthésique. En effet la sécrétion des cellules bêta est plus grande dans le premier cas. - Nous considérons la méthode employée valable pour des études ultérieures sur la sécrétion du pancréas de lapin.

Feinstruktur der B-Zellen von Pankreasschnitten inkubiert in vitro.

Zusammenfassung. In einem Schüttelbad wurden Schnitte vom Pankreasschwanz von Kaninchen bei $38^{\circ} \mathrm{C}$ mit Ringerpuffer inkubiert, der mit $0.6 \mathrm{mg} / \mathrm{ml}$ Glucose und $5 \mathrm{mM}$ Pyruvat, Fumarat und Glutamat angereichert war. - An der Feinstruktur der Inselzellen ließen sich keine signifikanten, der Inkubation zuzuschreibenden Veränderungen nachweisen. Durch kombinierte Fixierung mit Glutaraldehyd und Osmium ließen sich die Sekretionsprodukte der B-Zellen gut erhalten. Der Mechanismus der Degranulierung und Granulierung der B-Zellen war der gleiche wie er beim lebenden Tier beschrieben worden ist. Die Stärke der Sekretion war verschieden je nachdem, ob die Tiere nach einem zur Bewußtlosigkeit führendem Schlag getötet wurden oder ob ihnen eine tödliche Dosis eines Anaesthetikums injiziert wurde, und zwar war die Betazellsekretion im ersteren Fall stärker. - Diese Methode wird als geeignet angesehen, um mit ihr weitere Untersuchungen über den Machanismus der Synthese und Abgabe der Granula im Kaninchenpankreas durchzuführen.
The endocrine pancreas of different species has been studied by electron microscopic methods in different phases of its normal functional activity [3,9]. These investigations have established the synthesis, concentration, storage and release of the B-granules.

The present paper reports the cytological changes occuring in the B-cell of pieces of rabbit pancreas maintained in a shaking incubator for experimental periods of up to an hour. The response of the islet cells under these conditions permitted a study of the mechanisms of secretion as compared with the ones described in the animal in vivo.

\section{Material and methods}

Pancreas was obtained from fasted rabbits (both sexes $1.5-2 \mathrm{~kg}$ of body weight) decapitated after a blow on the head or after intravenous injection of Thiopenton. The tail of the pancreas was removed rapidly and pieces of this were incubated in $10 \mathrm{ml}$. of medium (Ringer solution supplemented with glucose $0.6 \mathrm{mg} / \mathrm{ml}$, pyruvate, fumarate and glutamate $5 \mathrm{mM}$ each) at $38^{\circ} \mathrm{C}$ in a gas phase $95 \% \mathrm{O}_{2}: 5 \% \mathrm{CO}_{2}[1]$.
Samples were taken at $0,15,30$ and 60 minutes. For electron microscopic studies the pieces were fixed in glutaraldehyde with Millonig buffer, washed with the same buffer and postfixed for 2 hours in $2 \%$ osmium tetroxide in Millonig buffer. The tissue was embedded in Epon 812 [4]. Sections were prepared in the routine manner and stained with lead acetate [8] or lead tartrate [6]. During the dehydration period the tissue was maintained overnight in a solution of $2 \%$ uranyl acetate in absolute alcohol. Sections were examined with a Siemens electron microscope, model Elmiskop I.

For light microscopy, pieces were fixed in Zenker solution and sections stained with Aldehyde Thionin [7].

Insulin content of the incubation medium was measured at the same intervals $(15,30$ and 60 minutes) by the radioimmunological method of HALES and RANDLe [2].

\section{Results and Discussion}

The ultrastructure of the B-cell has been described previously [3]. The B-cells of the rabbit have rounded or ovoid nuclei and contain nucleoli. The cytoplasm of B-cells contains many secretory granules of uniform 


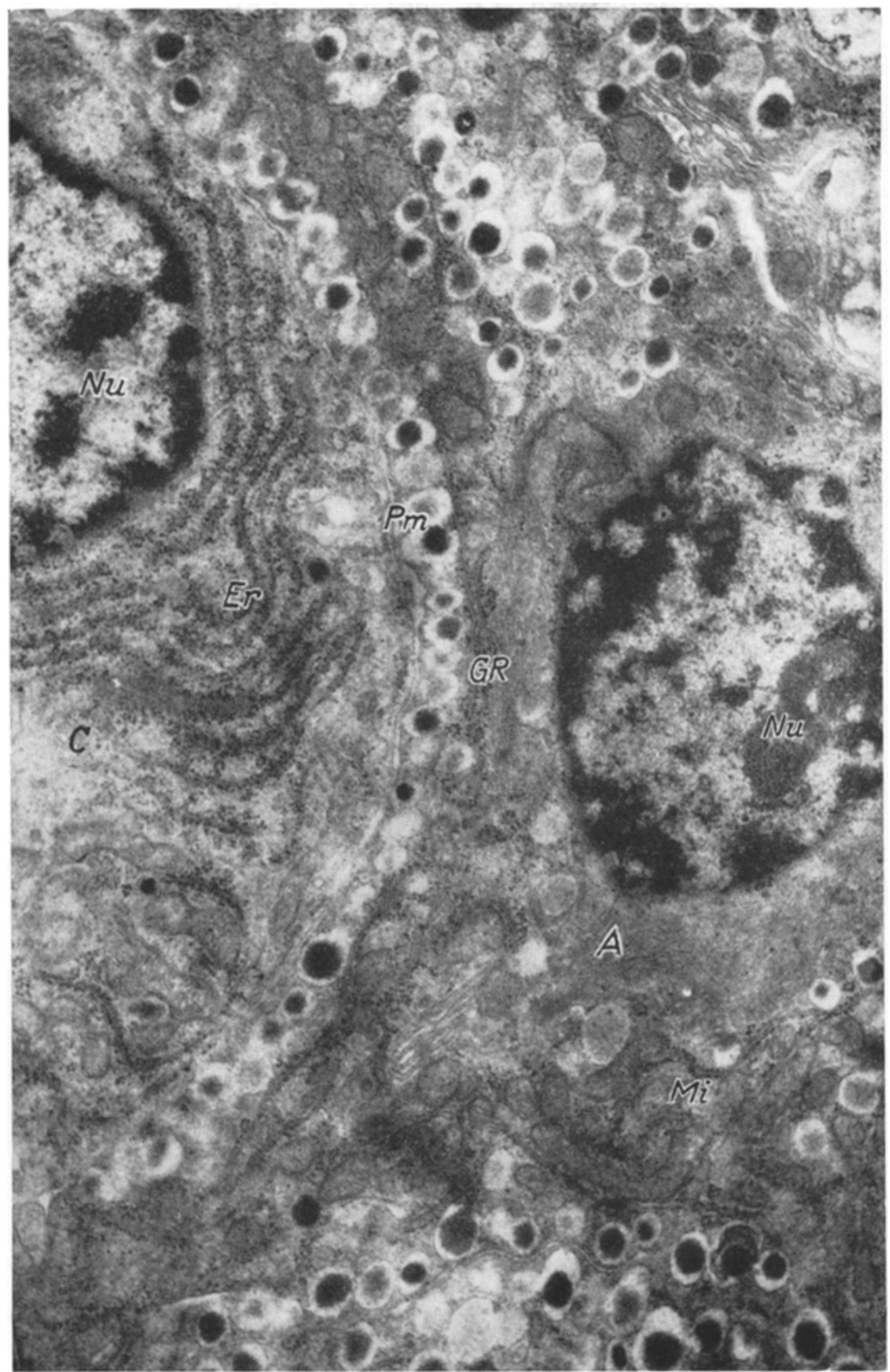

Fig. 1. B-cells of the rabbit at 15 minutes incubation time. In $A$ (B-cell with granules in margination). Mitochondria (Mi). Granules (GR). C In (B-cell, degranulated with hyperplasia of Lamellar Ergastoplasm (Er). Nucelus (Nu). Plasma membrane (Pm), x 19200

appearance. Their average diameter is approximately $180 \mathrm{~nm}$. Epithelial filaments [5] are usually present in a prominent band near the nucleus with no apparent relation with any of the organelles of the cell (Fig. 5). The other components of the cell are small distinct mitochondria and ergastoplasm and prominent Golgi complexes. Small projections of the islet cells protrude into the intercellular and pericapillary spaces.

With this type of preparation in combination with the immunoassay, we have examined the spontaneous secretion of insulin. The sources of all necessary chemicals and antibodies are as described by HaLES and RANDLE. The insulin output, in microunits per $10 \mathrm{ml}$ of incubation medium, is given in Table 1 :

Table 1

\begin{tabular}{lllll}
\hline Time in minutes & 15 & 30 & 60 \\
\hline $\begin{array}{l}\text { when rabbits are } \\
\text { knocked }\end{array}$ & & $1.500-1.100$ & $750-500$ & $0-200$ \\
$\begin{array}{l}\text { unconscious } \\
\text { when rabbits are } \\
\text { killed with } \\
\text { anaesthetic }\end{array}$ & $\left(6^{*}\right)$ & $650-400$ & $0-150$ & 0
\end{tabular}

(* number of experiments) 


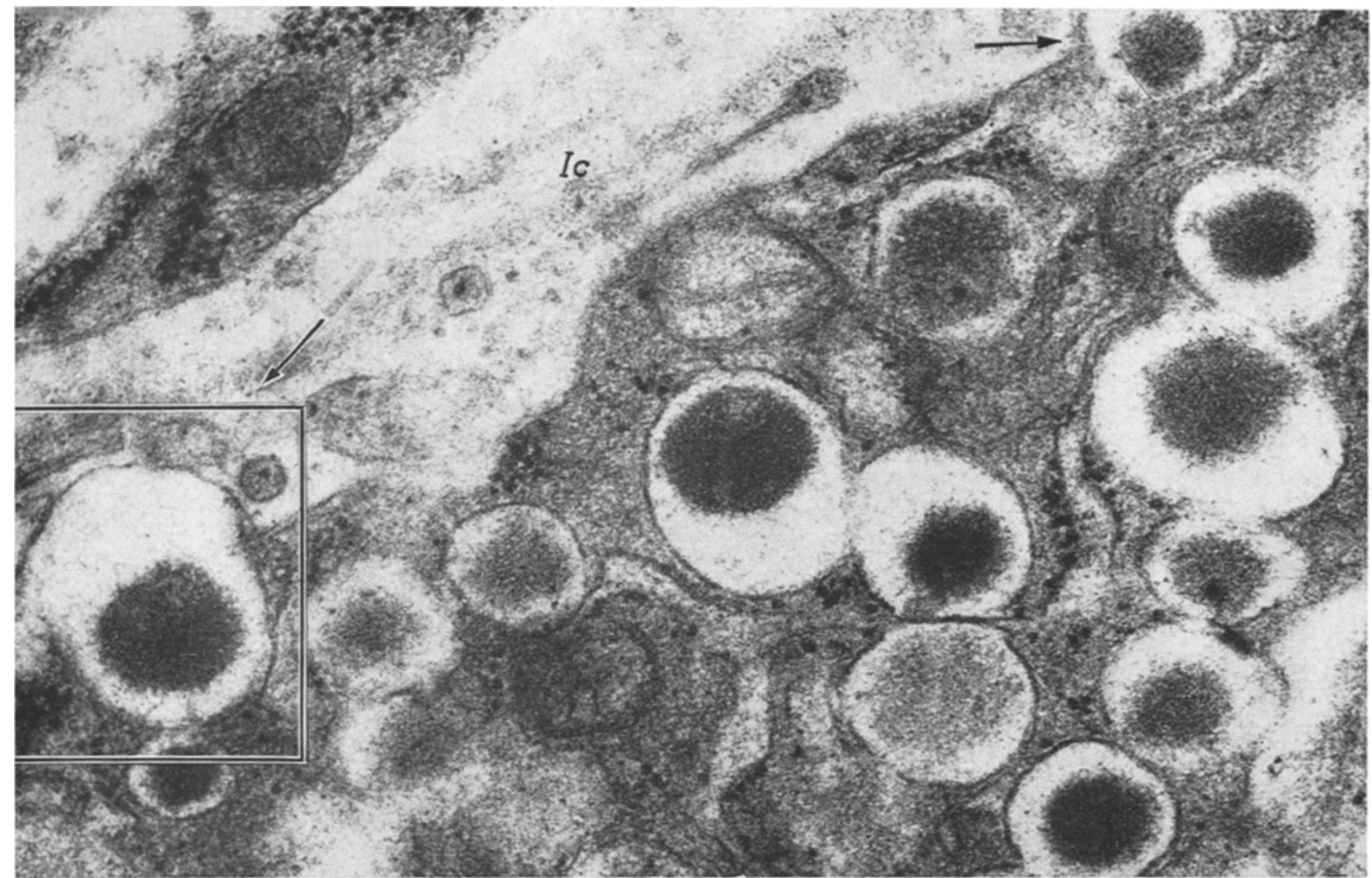

Fig. 2. B-cell of the rabbit at 15 minutes incubation time. Fusion of plasma membrane and enveloping sac $(\rightarrow)$. Intercapillary space (Ic). $x$ approx. 40000

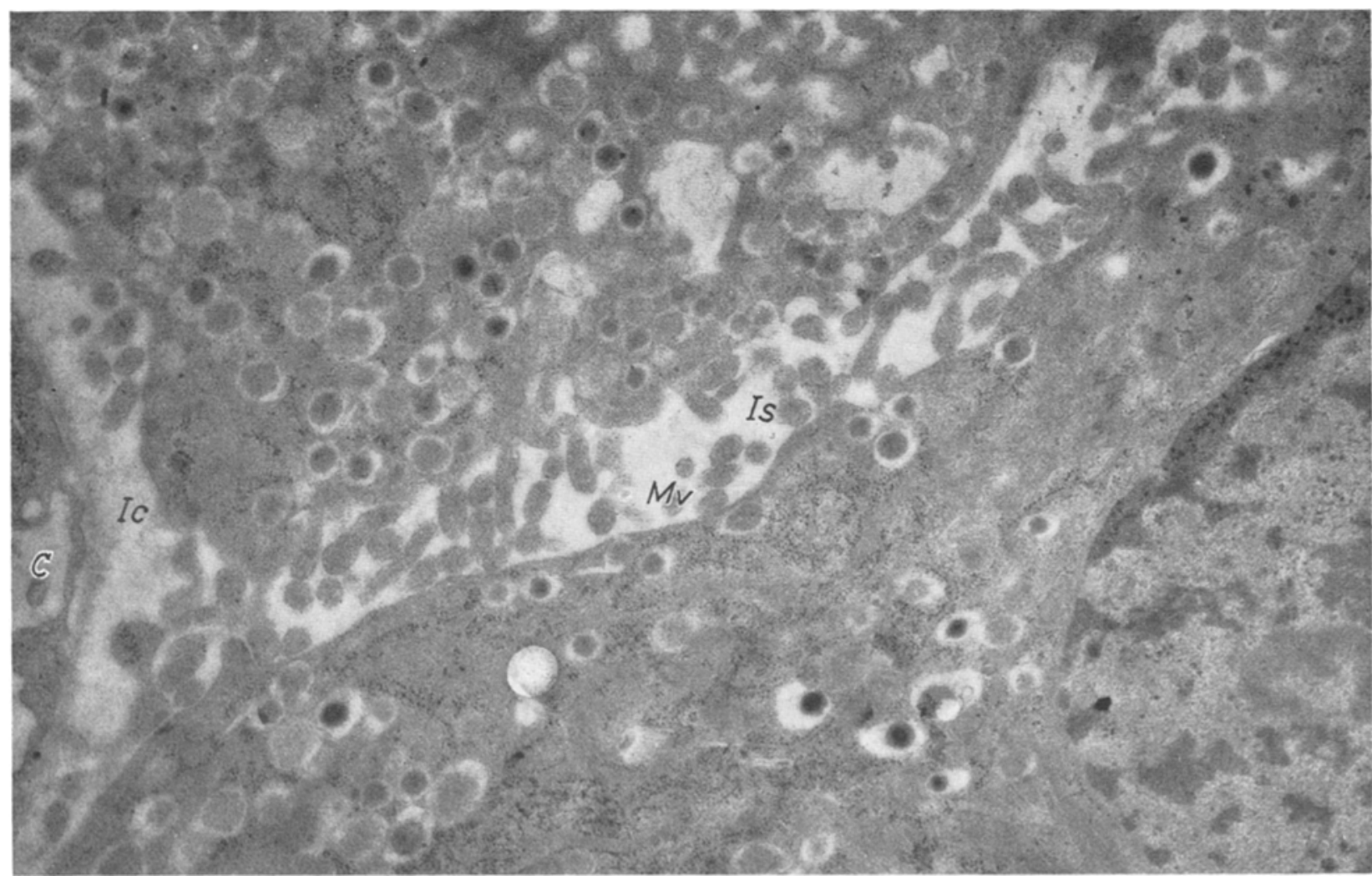

Fig. 3. B-cell of the rabbit at 15 minutes incubation time. Microvilli (Mv). Intercellular space (Is). Intercapillary space (Ic). Capillary (C). $x$ approx. 16000 


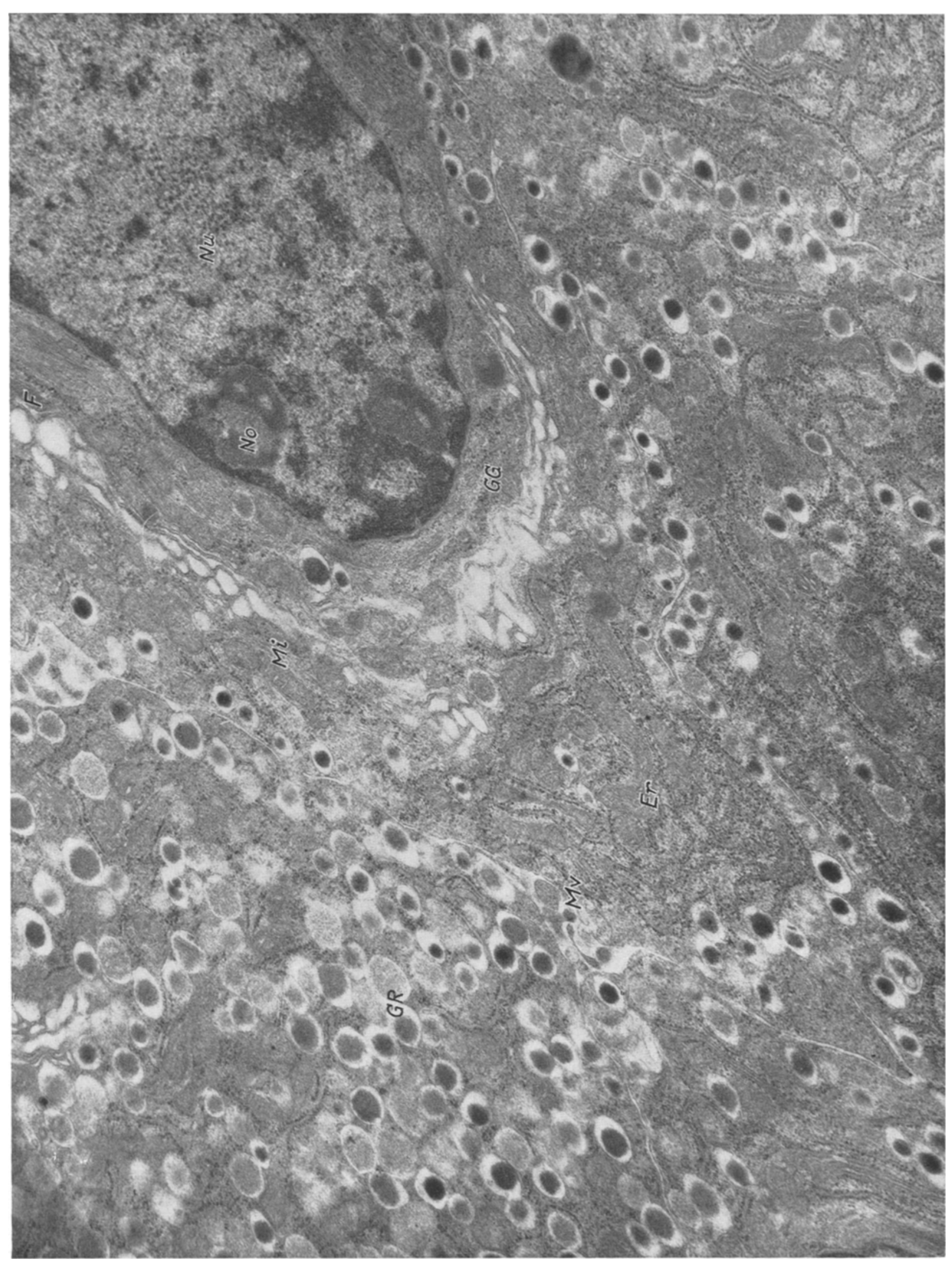

$\dot{\text { 它 }}$

멸

営

7

黄

它

常

密

宛

客

논

骂

苋运

둥

遏家

훙

究究

낭

.

安

焉

曹苞

粚

边

녕 벽

휴

突语

悹

\&

퐁

영 


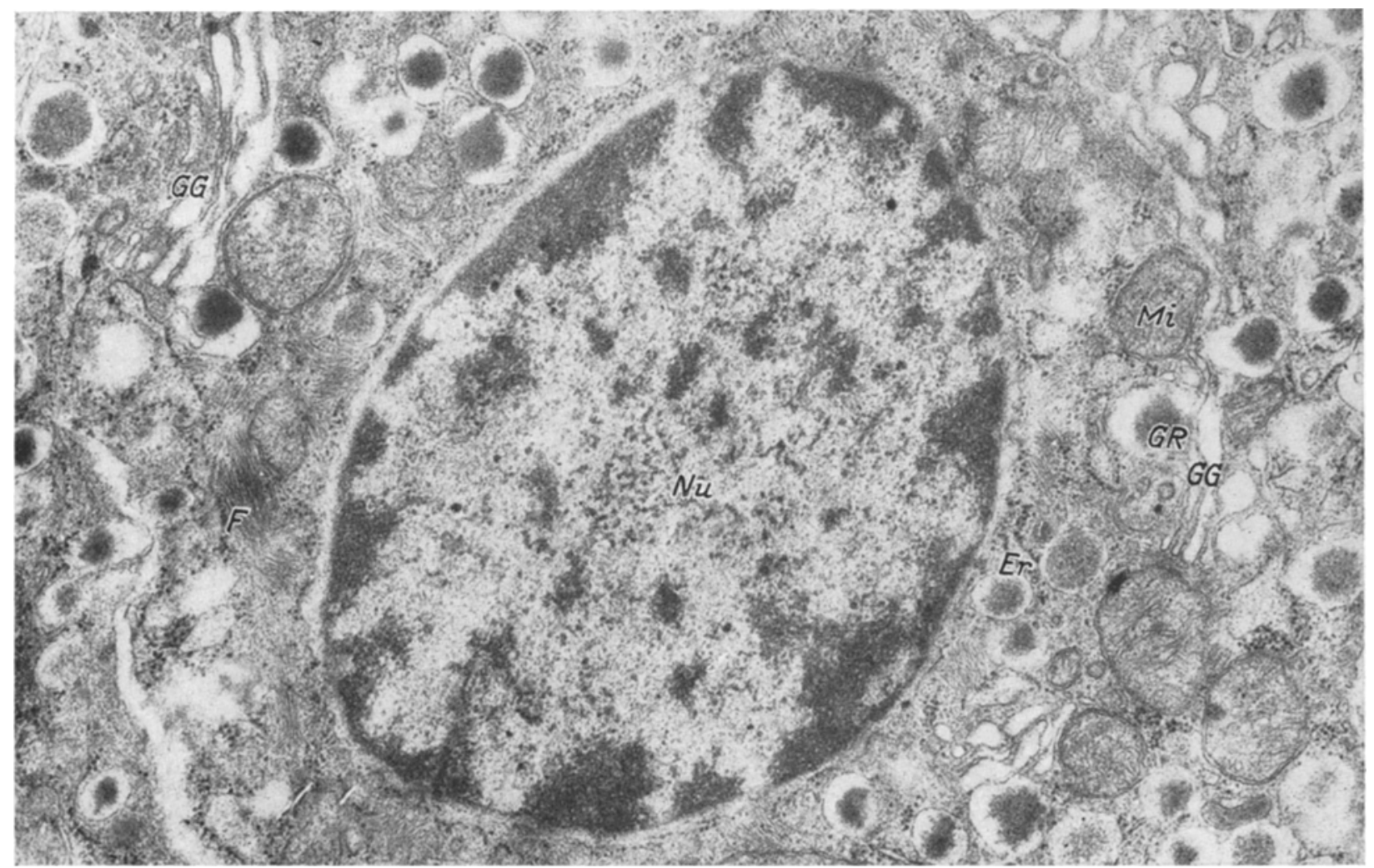

Fig. 5. B-cell of the rabbit at 30 minutes incubation time. No signs of secretory activity and well preserved structures. Granule (GR). Mitochondria (Mi). Golgi Vesicles (GG). Epithelial filaments (F). Lamellar Ergastoplasm (Er). Nucleus (Nu). x 64000

Samples taken at 15 minutes of the incubation period showed the following morphological picture: Many of the B-cells showed apparent margination of the B-granules with their surrounding sacs adjacent to the surface of the cell (Fig. 1) and in many instances the plasma membrane and the enveloping sac of the granules had fused and ruptured (Fig. 2); many cells showed increased numbers of microvilli projecting into the intercellular and pericapillary spaces (Fig. 3); some cells showed moderate or intense degranulation, and also contained an increased amount of lamellar and vesicular ergastoplasm (Figs. 1, 2). In all the cells the densities of the granules were variable. In many instances the granular sacs were empty or the granules appeared to be dissolving in their sacs. The rest of the cell structures were well preserved. The degranulation was also evident by light microscopy. The average insulin content of the incubation medium after the first 15 minutes was 1200 microunits when the animals were previously knocked unconscious, and 500 microunits when killed with a lethal dose of anaesthetic. This difference was also evident in the fine structure of the cells, since less signs of elimination of granules were present in the latter ease.

The cells of the samples taken after 30 minutes of incubation showed the following changes: many of the cells were moderately or intensely degranulated with hyperplasia of ergastoplasm (Fig. 4); a few cells showed no signs of secretory activity and had well preserved structures, except for occasional, slight swelling of mitochondria (Fig. 5), and occasionally margination and fusion of granules were noted. By light microscopy the B-cells were partially degranulated. The insulin content of the incubation medium was: 600 microunits average when the animals were knocked unconscious, and $0-150$ microunits when they were killed by anaesthesia.

After 60 minutes incubation time the following changes occurred: for the most part, the cells contained more granules than at 30 minutes; few were degranulated, and in some of them the ergastoplasm appeared vesicular with irregular contours (Fig. 6). The outer surface of these vesicles had attached ribonucleoprotein granules, and the lumen of these vesicles contained a pale amorphous material (Figs. 6, 7). The cellular structures were in general well preserved. The mitochondria showed increased density of their external membranes, inner cristae and matrix. Occasionally mitochondria showed disappearance of the inner cristae and dense matrix (Fig. 6). Rarely some were large, focally open and continuous with the cytoplasm. The B-cells examined by light microscopy showed less degranulation than the islets examined at 15 and 30 minutes incubation, although few degranulated cells were observed. The morphological changes occuring in the $\mathrm{A}$ and $\mathrm{D}$-cells during the 60 minutes incubation time will be described in a future paper. The ultrastructural changes observed in B-cells after 


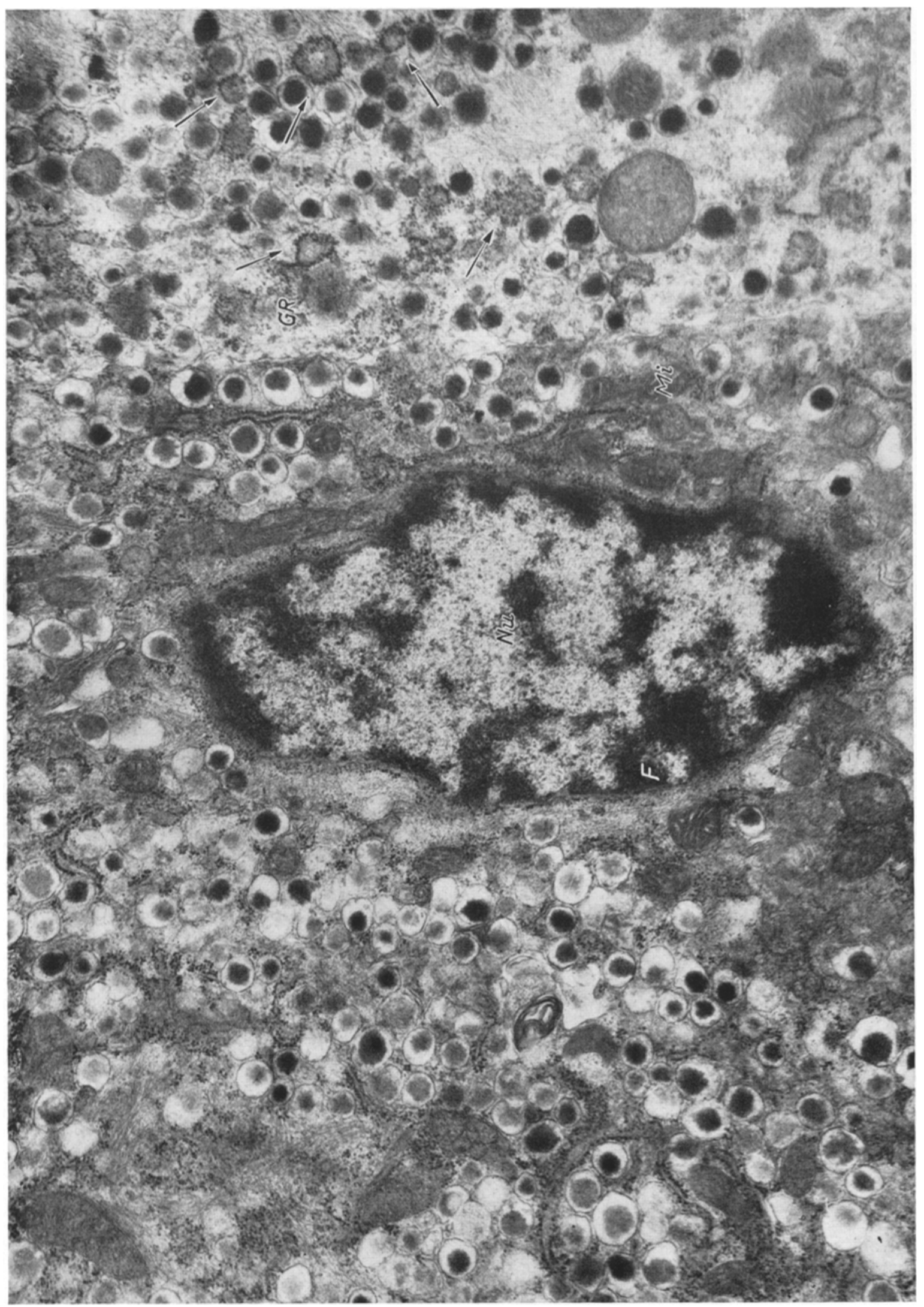


incubation of the pancreas slices, consist of (1) degranulation, (2) hyperplasia and vesiculation of ergastoplasm, and (3) partial regranulation.

The B-granules were released from the cells by a process of emiocytosis, the same as that described for the animals in vivo [9]. The intensity of ejection was greater when the animals were previously knocked unconscious than when they were killed with a lethal dose of thiopenton. This is also true with respect to hyperplasia and vesiculation of the ergastoplasm and
References

[1] Cooke, H.G., and P.J. RANDLE: Regulation of insulin secretion studied with pieces of rabbit pancreas incubated in vitro. Biochem. J. 93, 66-78 (1964).

[2] Hales, C.N., and P.J. RANDLE: Immunoassay of insulin with insulin-antibody precipitate. Biochem. J. $88,137-146(1963)$

[3] LACY, P.E.: Electron microscopy of the beta cell of the pancreas. Amer. J. Med. 31, 851 -859 (1961).

[4] LuF', J.H.: Improvements in epoxy-resin embedding methods. J. biophys. biochem. Cytol. 9, 409 (1961).

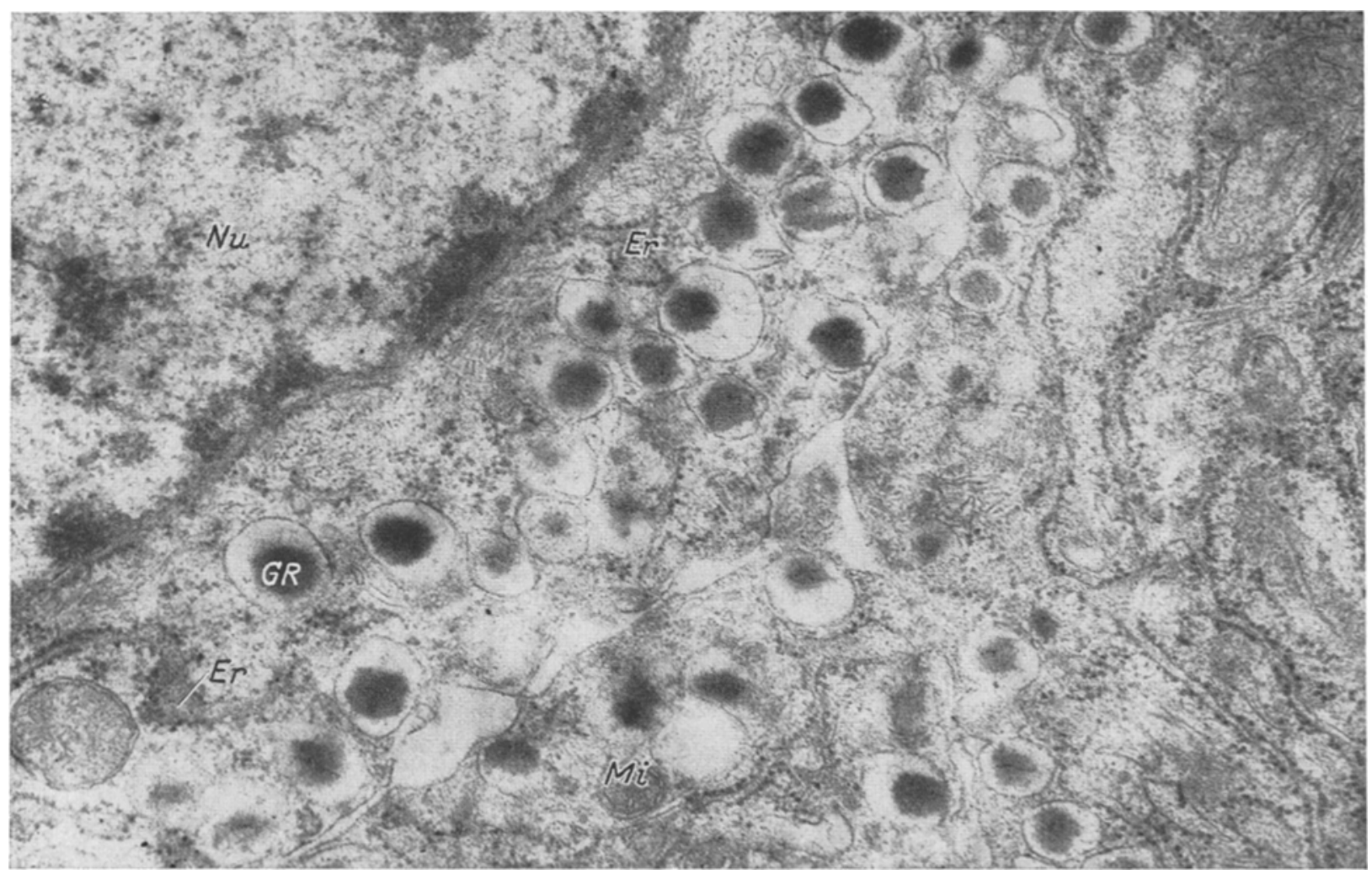

Fig. 7. B-cell of the rabbit at 60 minutes incubation time. Vesicular ergastoplasm. Dense mitochondria. Granules (GR). Vesicular ergastoplasm (Er). Pale amorphous material $(\rightarrow)$. Mitochondria (Mi). Nucleus (Nu). x 64000

regranulation. The degranulation was also evident by light microscopy. At 60 minutes it was somewhat less marked than at 15 or 30 minutes but still evident.

The fine structure of the B-cells was well preserved at 60 minutes incubation time and the changes described for the mitochondria may possibly be considered in relation to the biosynthetic condition of the cells.

Our experiments confirm that pieces of rabbit pancreas incubated in vitro under suitable conditions provide a controllable model for the behavior of B-cells.

Acknowledgements. The authors wish to express their gratitude to Dr. PAUL LACY for advice and assistance during the preparation of this manuscript. Our acknowledgement to Dr. M. RuBio and personnel of the Electron Mieroseope Service of the Centro de Investigaciones Biológicas of Madrid for their invaluable assistance. Valuable technical assistance was performed by Miss PAtrocrnto LOPEz. Part of this work has been done thanks to a. grant from Eli Lilly Co., Indiana. USA.
[5] Mercer, E.H., B.L. MUNGER, G.E. Rogers and S.I. Roth: A suggested nomenclature for fine structural components of keratin-like products of cells. Nature (Lond.) $201367-69$ (1963).

[6] Mirmonta, G.A.: A modified procedure for lead staining of thin sections. J. biophys. biochem. Cytol. 11, 736 (1961).

[7] PAGET, G.E.: Aldehyde-Thionin: a stain having similar properties to Aldehyde-Fuchsin. Stain Technol. 34, $223(1959)$.

[8] WATson, M.L.: Staining of tissue sections for electron microscopy. J. biophys. biochem. Cytol. 4, 475 (1958).

[9] Wultamson, J.R., P.E. Lacy and J.W. Prisham: Ultrastructural changes in islets of the rat produced by tolbutanide. Diabetes 10, $460-469$ (1961).

Dr. Josḱ Gomez-ACeBo

Instituto ,G. Marañon"s

Velazquez 144

Madrid 6 / Spain 